Asian J. Med. Biol. Res. 2020, 6 (4), 608-610; doi: 10.3329/ajmbr.v6i4.51224

\author{
Asian Journal of \\ Medical and Biological Research \\ ISSN 2411-4472 (Print) 2412-5571 (Online) \\ www.ebupress.com/journal/ajmbr
}

Review

\title{
Rice bakanae disease: an emerging threat to rice production in Bangladesh
}

\author{
Husna Asmaul ${ }^{1,2^{*}}$, Miah Md. Asaduzzaman ${ }^{2}$ and Nik Mohd Izham Mohamed Nor $^{1}$ \\ ${ }^{1}$ School of Biological Sciences, University Sains Malaysia, Malaysia \\ ${ }^{2}$ Dept. of Entomology, Patuakhali Science and Technology University, Bangladesh
}

"Corresponding author: Asmaul Husna, School of Biological Sciences, Universiti Sains Malaysia, Malaysia. Email: ahusna.pstu@yahoo.com

Received: 26 November 2020/Accepted: 21 December 2020/ Published: 31 December 2020

\begin{abstract}
Bakanae disease has been reported from almost all the rice growing countries in the world. The disease has been emerged as a major problem in some of the Asian countries including Bangladesh. Bakanae is becoming a serious threat to sustainable rice production in Bangladesh particularly in the northeastern part of the country and accounted for causing up to $25 \%$ yield losses. The disease has become difficult to manage due to lacking appropriate disease diagnosis. Fusarium fujikuroi mainly caused this disease but other Fusarium species are also reported to be involved for causing this disease. It, therefore, is crucial to understand the association of Fusarium species with Bakanae disease for sustainable rice disease management in Bangladesh.
\end{abstract}

Keywords: bakanae disease; Fusarium fujikuroi; sustainable disease management; Bangladesh

\section{Introduction}

Bangladesh is now the $3^{\text {rd }}$ rice producing country in the world after China and India. In Bangladesh, total rice growing area is 11.90 million ha which covers about $75 \%$ of the total cultivable area and the total production is 36 million metric tonnes (USDA Report, 2020). Rice is the main staple food crop in Bangladesh. The rice sector contributes one-half of the agricultural GDP and one-sixth of the national income. During cultivation, rice plant is infected by several diseases by fungus, bacteria, virus, nematode etc. and causing significant yield loss every year. Among the fungal diseases rice blast, brown spot, sheath blight etc. has been well known to cause huge yield loss but in recent years Bakanae is also causing considerable yield loss like a major disease. In fact, many minor diseases have been emerged as major one due to climate change, delayed sowing and transplanting, improper crop management practices etc. Bakanae, therefore, has become an important emerging disease across Bangladesh particularly in the northeastern part (Haor areas). Bakanae is mainly a seed borne disease but also survive in the soil. The pathogen is dispersed predominantly with infected seeds, infected crop residues from the previous season in the soil, or by conidia on diseased stems which can be transmitted by rain and wind (Gupta $e t$ al., 2015). The disease has been known as "Foolish seedling disease" that emerged as a significantly important disease in Asian rice growing countries including Bangladesh. Besides, Bakanae disease is called Hiska or Bejat or Dig as a local name in different areas of Bangladesh. In 1953, Bakanae was first detected in Bangladesh (Anonymous, 1958) by the Mycology and Plant Pathology Division, Bangladesh Agricultural Research Institute (BARI) but it was first described in Japan in 1828 (Ito, 1931). In Bangladesh, yield loss due to Bakanae was estimated up to $25 \%$ (Hossain et al., 2011) which has directly been affected into total rice production in Bangladesh. Farmers in Bangladesh mainly used fungicides other than cultural practices to manage Bakanae but the disease management has become increasingly difficult due to rapidly developing resistance to fungicide in the fungal population (Carter et al., 2008). It is believed that this disease is caused by Fusarium fujikuroi but other Fusarium species are also found to be involved in causing this disease. Interestingly, there is hardly any comprehensive study that describes the detailed information about the disease. The pathogen responsible for the disease has a number of races due to which breeding for the disease resistance faces problems. The aim of the paper, therefore, is to consider Bakanae as serious concern especially for the scientists to explore the Fusarium species associated with this disease for its effective control that will really benefit the rice growers, researchers and rice industries. 
2. Causal agent of Bakanae and symptoms

Bakanae is associated with several species of Fusarium but Fusarium fujikuroi Nirenberg (Syn: F. moniliforme (Sheld.) has been observed as the main causal pathogen (Wulff et al., 2010). Besides, F. proliferatum was also reported for causing bakanae disease in rice (Quazi et al., 2013). Seed contamination with this fungus provides initial foci for primary infection. F. fujikuroi may infect rice plants from pre-emergence to mature stage, with severe infection of rice seeds resulting in poor germination or withering (Iqbal et al., 2011). Bakanae is a seedling disease, but it can be observed throughout the growing season. Infected seedlings are appeared to be elongated, thinner and slightly chlorotic when compared with healthy seedlings. Symptom development is influenced by the amount of inoculum present, fungus strain and the relative quantities of gibberellin and fusaric acid. Besides, symptom development is affected by temperature, $35^{\circ} \mathrm{C}$ is optimum for disease symptoms development while it does not appear below $20^{\circ} \mathrm{C}$ (Hino and Furuta, 1968; Takeuchi, 1972). The incidence and severity of the Bakanae disease symptoms vary with regions and isolate.

\section{Bakanae in Bangladesh}

In Bangladesh, farmers cultivate rice almost in all three cropping seasons viz., Aus (April-June), Amon (JulyOctober) and Boro (December-March) with hybrid, high yielding variety (HYV) and local rice verities. Previously rice Bakanae disease was mostly observed in Aus season but nowadays the disease has been found commonly in Boro season. It is thought that excessive use of nitrogen fertilizer and favorable weather conditions $\left(30^{\circ} \mathrm{C}-35^{\circ} \mathrm{C}\right)$ are responsible for causing Bakanae in Bangladesh. Almost all cultivated rice varieties in Bangladesh are more or less susceptible to Bakanae disease (Hossain et al., 2011). Among them, BRRI Dhan 29, BRRI Dhan 58 were found as the most susceptible to Bakanae which has been cultivated in Boro season.

In recent years, Bakanae disease has been found to occur commonly with high incidence in the Haor areas of Bangladesh compared to other areas. Geographically, seven districts of North-East Bangladesh like- Sunamganj, Kishoreganj, Netrokona, Sylhet, Habiganj, Maulavibazar and B. Baria comprise most of the haor areas. In these seven districts, total cultivated area is about 1.26 million hectares which produce more than 5.25 million tons of paddy per year (Alam et al., 2010; Huda, 2004). Rice is the main cultivated crop in haor areas. About $88 \%$ of the total area under the haor districts falls under the rice cropping area (DAE, 2008). It is important to mention that Haor areas contribute 18\% to the national rice production (Huq, 2012). In most of the haor areas, BRRI Dhan 58, BRRI Dhan 29, BRRI Dhan 28, BR-19, BR-14, Gochi, Rata has been cultivated as the prominent Boro varieties. Among them, BRRI dhan 29 ranked first in respect of percent of cultivated farmers $(92.20 \%)$ and areas (58.30\%) (Muttaleb et al., 2008). Significant disease incidence was recorded in the most cultivated variety BRRI Dhan 29. In our recent survey, BRRI Dhan 58 was also found as most susceptible to this disease. In Bangladesh, a virulent pathogen with a plentiful amount of susceptible host exists and therefore, there is a possibility for this disease to reach at an epidemic level in the near future if a favorable environment exists.

Regarding Bakanae disease, a limited number of research has been conducted to find Bakanae resistance varieties. Accordingly, 87 rice varieties (46 BRRI released varieties, 40 landraces of BRRI germplasm and a Chinese variety "Purbachi") were tested where BRRI varieties was found comparatively higher susceptible than the landraces (Hossain et al., 2015). Among them, BRRI Dhan 40, 30, 44, 32, 28, 29, 24, 25, 26, BR 8, 9, 10 were found as the most susceptible varieties while BR 23 and BR 11 were found as lower susceptible variety (Hossain et al., 2015). Interestingly, most of the farmers used BRRI released varieties though they are susceptible (Hossain et al., 2011). Besides, farmers in Bangladesh, especially in the haor area, has been used the rice seeds for planting from their previous yield rather than purchased new seeds. For sowing purposes, every year they kept some rice seeds for the next season. Moreover, they used the seeds for sowing without proper seed treatment. Though there are a lot of hybrids and HYV varieties, farmers are comfortable to cultivate with BRRI Dhan 28, BRRI Dhan 29, BRRI Dhan 58 etc. to get more yield. Even they are not willing to cultivate new hybrid varieties as they believe that other varieties are not high yielding. Thus, Bakanae pathogen is remained in the same land year after year and transmits from seed to soil or soil to seed.

\section{Management of Bakanae}

To minimize the yield loss, Bakanae need to manage. According to Gupta et al. (2015), use of clean noninfected seed, hot water treatment, proper selection of geographical area, time and method of nursery sowing and transplanting, removal and destruction of infected plants from the field and balanced fertilization help in reducing the incidence of bakanae disease by minimizing the inoculum and seed-borne infection of the pathogen. However, the most effective and profitable strategy is to follow an integrated approach that uses several techniques like crops rotation, using resistant varieties, planting in warm soil, use balanced fertilizer, seed treatment with appropriate fungicides etc. 


\section{Conclusions and Recommendations}

For sustainable disease management, it is crucial to find out an innovative effective management technique other than traditional practices. Therefore, carrying out research on Bakanae pathogen like pathogen variability, pathogen association, host-pathogen interaction, molecular pathogenesis, racial profiling, secondary metabolites, and mycotoxin profiling is needful. In fact, an accurate diagnosis of plant disease is essential before selecting a management technique. Interestingly, Fusarium species associated with Bakanae disease, are still unknown in Bangladesh. Thus, identification of Fusarium species association for Bakanae may facilitate proper diagnosis as well as effective management of this disease.

\section{Acknowledgements}

I would like to thank Md. Matiul Alam, Md. Tareq Abu Sayeed and Md. Sadiq Shaon, Upozila Agricultural Officer, Department of Agriculture Extension, Bangladesh for providing information.

\section{Conflict of interest}

None to declare.

\section{References}

Alam MS, M Quayum and M Islam, 2010. Crop production in the Haor areas of Bangladesh: insights from farm level survey. The Agriculturists, 8:88-97.

Anonymous, 1958. Annual report of the Mycology and Plant Pathology Division: Agricultural Research Institute, Govt, of East pakistan for the year 1957-58.

Carter LLA, JF Leslie and RK Webster, 2008. Population structure of Fusarium fujikuroi from California rice and water grass. Phytopathology, 98: 992-998.

DAE R, 2008. Department of Agricultural Extension (DAE) Annual Report. Department of Agricultural Extension, Field Crops wing, Khamar Bari, Farmgate, Dhaka-1215.

Gupta A, I Solanki, B Bashyal, Y Singh and K Srivastava, 2015. Bakanae of rice-an emerging disease in Asia. J. Anim. Plant Sci., 25: 1499-1514.

Hino T and T Furuta, 1968. Studies on the control of bakanae disease of rice plants, caused by Gibberella fujikuroi. 2 Influence on flowering season on rice plants and seed transmissibility through flower infection. Bull Chugoku Agric Exp Station E 2: 96-110.

Hossain K, MT Mia and M Bashar, 2015. Management of Bakanae disease of rice. Bangladesh Journal of Botany, 44: 277-283.

Hossain K, M Miah and M Bashar, 2011. Preferred rice varieties, seed source, disease incidence and loss assessment in bakanae disease. J. Agrofor. Environ., 5: 125-128.

Huda M, 2004. Experience with modern and hybrid rice varieties in haor ecosystem: Emerging Technologies for Sustainable Rice Production. Paper presented at the Twentieth national workshop on rice research and extension in Bangladesh. Bangladesh Rice Research Institute. Gazipur-1701.

Huq S, AKMA Rahman, SMI Ali, P Moeller and P Gnoyke, 2012. Community Based Adaptation to Climate Change in Bangladesh Community Based Adaptation to Climate Change in Bangladesh. Paper presented at the Conference Proceedings on 1st National Conference, Dhaka, Bangladesh.

Iqbal M, N Javed, ST Sahi and NM Cheema, 2011. Genetic management of bakanae disease of rice and evaluation of various fungicides against Fusarium moniliforme in vitro. J. Phytopathol., 23: 103-107.

Ito S, 1931. Studies on the bakanae disease of the rice plant. Rep. Hokkaido Agric. Exp. Stn., 27: 1-95.

Muttaleb M, M Jalil, A Paul, S Habib and M Hossain, 2008. Diversity of Rice Varieties in Some Selected Haor Areas of Sunamganj District. International Journal of Sustainable Crop Production, 3: 31-34.

Quazi SA, S Meon, H Jaafar and Z Abidin, 2013. Characterization of Fusarium proliferatum through species specific primers and its virulence on rice seeds. International Journal of Agriculture and Biology, 15: 649656.

Takeuchi S, 1972. Climatic effect on seed infection of rice plant with bakanae disease and disinfection with organic mercury compounds. Proc. Kansai Pl Prot. Soc., 14: 14-19.

USDA Report, 2020. World Agricultural Production, Foreign Agricultural Service United States Department of Agriculture

Wulff EG, JL Sørensen, M Lübeck, KF Nielsen, U Thrane and J Torp, 2010. Fusarium spp. associated with rice Bakanae: ecology, genetic diversity, pathogenicity and toxigenicity. Environmental Microbiology, 12: 649657. 